\title{
PSYCHOLOGICAL CULTURE OF A CLASS TEACHER AS THE FOUNDATION OF MODERN SCHOOLCHILDREN'S PSYCHOLOGICAL SECURITY
}

\author{
Tatyana I. Kulikova \\ Leo Tolstoy Tula state pedagogical university \\ Tula, Russia
}

\begin{abstract}
This article discusses the role that psychological culture of class teacher plays in the establishment and maintenance of psychological safety in a modern schoolchild. The problem of protection against psychological abuse within the educational environment of a school is particularly important in the current socio-cultural realm. The article analyzes many pedagogical and psychological studies regarding the problem of psychological education of teachers. It discusses contradiction between the objective need to create a psychologically safe learning environment and the unwillingness of teachers to work on it due to low own level of psychological culture. The author introduced the original structural model of psychological culture of a class teacher, representing the integration of the three main components: the culture of pedagogical reflection, emotional culture and culture of pedagogical influence.
\end{abstract}

Keywords: psychological culture, psychological safety, class teacher, modern schoolchildren.

Today's socio-cultural situation is responsible for many examples of negative impact on the formation of personality traits that external factors make. This increases the need for social, psychological and physical security in otherwise unstable social situation. According to many psychological and sociological studies, large percentage of parents is concerned with their child's safety within the educational environment. Parents are concerned about the way their children feel at school, whether they are accepted, understood, positively regarded, respected and loved regardless of their academic success. But they are even more concerned about destructive effects of psychological or physical abuse and bullying their children get from their peers, older children, and, sometimes, teachers. 
The analysis of several studies (G.V. Grachev, T.S. Kabachenko, I.A. Baeva) showed that the effectiveness of educational process depends on the psychological security of the educational environment. Psychologically safe educational environment actualizes personality's potential, and strengthens the ability to cope with life difficulties.

The works of many Russian psychologists present great interest in the light of the psychological security problem. Among them are K.A. Abulkhanova-Slavskaya, A.G. Asmolov, A.L. Zhuravlev, M.M. Kashapov, B.D. Parygin, V.V. Rubtsov, N.P. Fetiskin; theoretical studies of psychological safety of the subject are given in the works of I.A. Baeva, M.A. Kotik, V.M. Lvov, N.L. Shlykova; the characteristics of the psychology of educational environment are described in the works of I.A. Baeva, A.A. Rean, V.V. Rubtsov, E.A. Peskovky, S.G. Pleschits, D.I. Feldstein, G.P. Schedrovsky, V.A. Levin), and other. According to O.E. Lebedeva, the integral psychological safety indicator of the educational environment should be a feeling of emotional well-being shared by all participants of the educational process, which is a prerequisite of effective personal development of both teachers and schoolchildren.

In this connection the issue of psychological safety or a culture of one in interactions within an educational environment seems extremely important. The psychological culture stems from the culture of teaching and pedagogical interaction. It is the psychological culture that forms the essential professional qualities of teachers, and ensures efficiency of educational process.

According to a number of Russian researches on the problem of teacher's psychological literacy, it seems that the current system of psychological education doesn't aim at fostering psychological culture in teachers. The current practice of teacher's training focuses more on courses, and their content, so most of the class time is spent on learning practical disciplines. Considerably less time is devoted to psychologicalpedagogical subjects, which does not instill important aspects of professional conduct into personality of future teachers.

It seems very important to study influence of teacher's psychological culture on schoolchildren's psychological safety. It seems even more important to define the alternative educational methods that would foster the development of future teachers' psychological culture. Currently, none of the teacher universities and colleges prepares a future teacher for 
assuming the position of a class teacher ${ }^{1}$, which further widens the gap between a modern teacher's personal and professional qualities, and the requirements of class teacher duties.

Being a class teacher is a responsibility voluntarily assumed by teaches in addition to their main activity. A class teacher is the primary organizer of educational work in schools, and is officially appointed by the school principal to organize educational process of their class. A class teacher:

- mediates the society and the developing personalities of schoolchildren in their learning about the cultural foundations of humankind;

- manages relations between all elements of the educational process;

- creates optimal psychological climate in classrooms;

- coordinates joint efforts of teachers, family and society;

- organizes daily life of children, and is an important role-model in individual development of a child.

For professionally competent, successful and effective realization of their duties, class teachers ought to be familiar with the psychological and pedagogical basics of working with children of specific age, be informed about the latest advancements in forms and methods of educational work, know and use modern educational technologies.

The central element of the class teacher professionalism is his or her professional psychological-pedagogical competence, the understanding of the complexity of personality, ability to analyze interaction of schoolchildren with the world, and manifestations of the schoolchild's interpersonal relations with other people. Thus, the psychological culture can be viewed as a part of psychological and pedagogical competence of a class teacher.

Broadly put, psychological culture is related to a person's inner life thoughts, feelings, emotional states, and interpersonal relations - all that constitutes one's psychological reality. In psychological terms, a man of culture is not the one who read many books on psychology and talks lot

${ }^{1}$ In Russian school system every class is assigned with a teacher who takes on the responsibility for its academic success and supervises it from primary school to graduation. Such position is called "the class teacher". 
of sophisticated professional jargon, but the one to whom the subtle psychological realm is as real as any material object in the world.

Psychological understanding of culture defines people as both cultural objects and subjects, and this demands that to the definition of culture should be added with a set of values, norms and ideals, actively internalized by people and used by them in interactions with others.

According to I.A. Zimnyaya (2005), general culture is determined by the state, stability, and prominence of the formed attitudes towards the outside world and oneself. It requires the presence of internal culture (tact, dignity, respect for others, responsibility, self-regulation). We believe that internal culture is psychological culture - a certain quality of a person's psyche. Therefore one's psychological culture underlies their general culture. Psychological culture is a culture of behavior and culture of communication, culture of interrelations, culture of intellectual activity, and culture of self-regulation.

The foundations of the psychological culture concept can be found in the works of such renowned Russian and foreign psychologists as W. Wundt, S. Freud, C. Jung, A. Maslow, M. Cole, K.D. Ushinsky, M.Ya. Basov, L.S. Vygotsky, B.G. Ananiev, S.L. Rubinstein, as well as in certain works of contemporary psychologists.

L.S. Vygotsky and his school of thought developed cultural-historical approach to psychology. The most interesting in the respect of this work are the three basic concepts that Vygotsky distinguished in his work "History of the development of higher mental functions": 1) the notion of higher mental function, 2) the notion of cultural development of behavior, and 3) the notion of mastering own behavioral processes. According to his theory, the most important factor that determines the development of mental functions is culture, and at that everything cultural is social. Therefore, culture is a product of social life and social activities of a man.

Psychological culture as part of the general culture is multilayered. It includes: 1) everyday psychological knowledge, and psychological practices of religious, social, political, economic, and educational activities, 2) professional experience and practical knowledge in the field of psychology, both as a science and an art (psychotechnics, various schools of counseling and therapy), and 3) the psychological science and education (mostly higher education), that form psychological domain. 
Individual psychological culture should not be viewed outside the culture one grows up and lives in. It contains features of both world and national cultures, "absorbing" their wealth. Culture is a global treasury of the humanity's past that supports its future. Culture connects people with each other and with their inner selves.

In the light of this differentiation we view the concept of "basic psychological culture" as a multi-component systemic formation that can be viewed from the standpoints of gnosiological, activity, and subjectivepersonal aspects.

From the gnosiological standpoint we consider philosophical and culturological, components of culture: norms, knowledge, values, and symbols. Cultural norms are associated with normative social behavior, its roles, social expectations, etc. At the same time the adoption of norms leads to internalization of such psychological legacies of culture, as prejudice, stereotypes that manifest themselves in consciousness, subconscious and behavior. Psychological knowledge formed by a person's attempts to know oneself or other people and by the developments of science, expressed in ideas, notions, or theories, can be both practical and theoretical. Meanings - the cultural tools for connection with the world through the medium of signs - are expressed with images, symbols, gestures, words, clothing, etc. Symbols in the field of psychology may be a subject of analysis in terms of the various manifestations of mental activity (fairytales, dreams, metaphors, etc.), their interpretation, assignment of personal meanings and an impact on a person's activities.

From the activity standpoint we consider the tasks that a man needs to perform. This aspect considers the content of the activity that underlies internalization of human culture. Entering the world of psychological culture, much like any other culture, is done in two ways: through the reproduction of the experience familiar to humankind and through creativity - the "discovery" of truth, understanding psychological phenomena, or by insights.

From the subjective-personal standpoint we consider the components objectively presented in culture that became part of personality of the person who internalized them. Psychological culture of personality is, above all, the phenomenon that permeates every aspect of people's psyche and activity. The first attempt to study psychological culture as an independent psychological phenomenon was made by L.S. Kolmogorova (Kolmogorova \& Holodkova, 2001): "The psychological culture 
is an integral part of the basic culture of personality that enables one to be self-defined and self-actualized in the real life, contributing to successful social adaptation, self-development, and the experience of joy of living."

Presently, there are a lot of studies examining various aspects and the constituent elements of psychological culture. For example, E.A. Klimov introduced the concept of psychological literacy, as a certain level of psychological culture, pointing out the "soul searching" aspect of cognition, interest in other person, and skills of gaining psychological knowledge (Klimov, 2004).

V.M. Allakhverdov (Allakhverdov, Beljak, \& Ivanov, 1985), investigating the "psychological insight" as a certain component of psychological culture, observes that the lack of psychological insight is the lack of an effective tool in building one's behavior.

L.B. Kulikov (1995), viewing psychological culture from the standpoint of ethnic psychology, regards this concept to be a subject of psychoculturology - an interdisciplinary science that embraces culturology, psychology, ethnology, anthropology, and sociology.

The concept of psychological culture according to N.N. Obozov (1986) includes: 1) knowledge of and understanding self and others, 2) adequate self-esteem and regard for other people, 3) self-regulation of personal characteristics, self-regulation of one's activity and interaction with other people.

According to O.I. Motkov (1999), psychological culture is a set of acquired needs, abilities and skills of a person. Psychological culture manifests itself in self-organization and self-control of people, their basic aspirations and tendencies, their attitude towards one's personality, the others, animate and inanimate nature, and the world in general. With psychological culture one can more harmoniously feel the needs of his own mind and body, as well as external demands of life.

Consideration of the psychological culture phenomenon within an educational context is attributed to the fact that the pedagogical reality needs to introduce the emotional component to the educational process and actualize personal resources of its participants. Psychological culture is a socio-psychological mechanism of effective adaptation within the society; it facilitates social and cultural interaction and plays an important role in maintaining psychological health and quality of all activities, including the educational one. 
A certain level of psychological culture allows us to characterize human behavior, learn about the peculiarities of one's regard for other people, the depth of one's understanding of the nature of experiences associated with another person, the system of relationships, an ability to communicate and collaborate, work, etc. Thus, the psychological culture is a unity of knowledge, attitudes, feelings and life experience.

Ideally, psychological culture is a high quality of self-organization and self-regulation of one's various basic needs and aspirations, their attitudes (towards themselves, close and distant people, animate and inanimate nature, to the world in general). Psychological culture, along with an optimal lifestyle, facilitates stable and harmonious functioning of an individual.

In terms of inner harmony, O.I. Motkov points out the following manifestations of psychological culture:

- Predominant feeling of wellbeing;

- Thorough understanding and acceptance of oneself;

- Positive attitude in managing everyday responsibilities and leisure time

- Joy of life, satisfaction with one's interpersonal relations with other people, the way everything goes, one's health, lifestyle, creative activity;

- High enough level of regulating one's desires, emotions, actions, habits,

The study of various aspects of psychological culture can be found in the works of other prominent Russian psychologists. Thus, M.Ya. Basov (1975), as educational psychologist, was interested in reasons why teachers, whose everyday professional activity is to observe children, aren't taught to be observant. He points out that the culture of observation is as an important professional skill that each teacher must develop and employ. M.Ya. Basov emphasizes the importance for a teacher to be an effective explorer and researcher of the child, trying to notice every subtle detail of their behavior in order to adjust their teaching means and strategies.

Without a doubt it was the psychological culture of a teacher that B.G. Ananiev kept in mind when writing in his work "Man as an object of knowledge", that an experienced teacher achieves the heights of effectiveness in education through the deep knowledge of his or her students, of their characteristics, social behavior, personality traits and motives (Ananiev, 2001). 
A.A. Bodalev (2002), while reflecting on the qualities of teachers in regard to psychological culture, points out the following of them: the ability to empathize with schoolchildren, to sympathize with them, to be open, to feel as a part of a child's "victories" and "defeats". According to him, these qualities are the foundation upon which a teacher stands, prerequisite to establishment of respectful relationships with children.

A.B. Orlov (2002), defining the humanization of education as people's constructive self-change, means by it the formation of a special, psychological culture. Child upbringing is transferring the culture (knowledge and values) from one generation to another. True psychological culture of teachers is the culture of their beliefs, experiences, ideas and influences, manifested in their attitude towards their selves and their students.

Psychological culture is regarded as an integral characteristic of the educational environment, along with psychological security, which assures psychological health of schoolchildren and teachers. Psychological culture is a major factor in and a prerequisite to creation of the safe learning environment, which exists in the culture of teaching and the culture of interaction. As rightly noted by V.P. Zinchenko and E.G. Morgunov (1994): "We shouldn't construct, or even 'form' a certain personality. A schoolchild only needs to be assisted (or at least spared from interference) in becoming his or her own self. It seems that this is the one true philosophy of cultural pedagogy, a pedagogy, which activity should be more responsible than responsive."

Based on the analysis of various approaches to understanding the psychological culture of the teacher, we believe it is possible to present the structural model of psychological culture of class teacher (Fig. 1).

True psychological culture of teachers is the culture of their beliefs, experiences, ideas and influences, manifested in their attitude towards themselves and their students. Applying the components of psychological culture on personality of class teacher, it is necessary to emphasize the interconnection of the three main components: culture of pedagogical reflection, emotional culture, and culture of pedagogical influence. The mediating psychological aspects of a class teacher culture are psychological literacy and psychological health (Kulikova, 2008).

Psychological literacy (Klimov, 2004), being the minimum requirement of the psychological culture, assumes integrity of personality and a certain mind-set. Psychological literacy may manifest itself in broad 


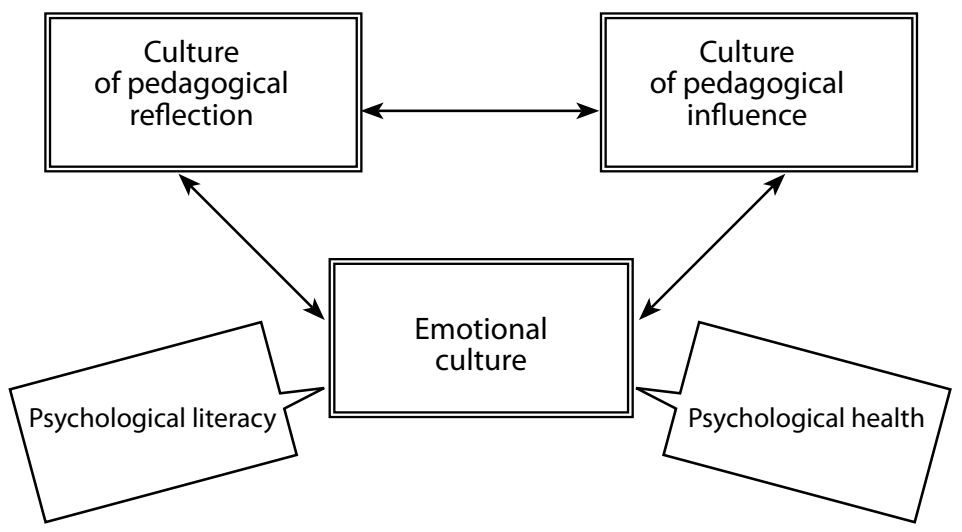

Figure 1. Structural model of psychological culture of class teacher

general knowledge about various psychological phenomena, gained by both scientific and everyday experience, derived from traditions, customs, direct contacts with other people, learned from the mass media, and so on.

The lack of basic psychological literacy is the main reason for many problems, difficulties, conflicts, stress, and emotional hurt in the life and work of both individuals, and the society as a whole. As noted by I.V. Dubrovina (2000), our society need more psychological knowledge and psychological culture, that facilitates interest in another people, respect for their personalities, and a willingness to understand other people's actions, attitudes, and feelings.

Psychological health, though not included in the structure of psychological culture of personality, mediates its various aspects. Psychological health is the result of normal development of the subjective reality within an individual. It characterizes the person as a whole, shapes the manifestations of one's spirit and serves as a diagnostic indicator of possible problems in the psychological domain of a person (Dubrovina, 2000).

The modern interpretation of psychological health states positive attitude towards themselves, the optimal mental development, personal growth and self-actualization, mental integration, balance, personal autonomy, appropriate social behavior, the ability to understand self and others, the ability to make choices and take responsibility for it. 
The self-reflective component of class teachers' psychological culture is their idea of themselves. Often the case, teachers have limited perception of their roles in school - of merely performers of their social roles. This perception diminishes teacher's individuality, because a person is always bigger than his or her social role. The personality-oriented education, in terms of which we view the self-reflective component of teacher's activities, focuses on the development of personal-semantic sphere of a class teacher - an ability to reflect on the reality and its value.

Reflection is meditation on the goals, process and the results of one's internalization of culture, as well as awareness of the inner changes in one's personality. Reflection is both the main cognitive mean of selfawareness and self-regulation, and a mechanism of self-development.

A class teacher should know the culture of self-acceptance and be able to express him- or herself in many different and sometimes unexpected qualities, feelings, actions. The high level of self-acceptance determines not only stable Self-concept, but also such of other people (C. Rogers). According to R. Burns, the consequence of low self-acceptance - an inadequate self-esteem and rejection of certain qualities of own personality - lead to insecurities and hinder harmonious relationships with the others. Such class teacher is unable to accept schoolchildren as they are and denies them the right to be themselves, which, in its turn, hinders communication between them.

The problem of self-acceptance in the teaching profession, viewed in the context of psychological culture, was studied by A.B. Orlov (2002). He considers teacher's Self-concept to be the self-reflective component of psychological culture and notes that teachers perceive themselves at school through their social roles, through the image of the Ideal Teacher. And since in the real life this ideal is impossible to reach, this "puts teachers in the position of constant underachievers, which inevitably affects their self-esteem (and Self-concept in general). Moreover, selfperception and self-manifestation of teachers, mediated by this position, not only severely constrict and distorts their Self-concept and behavior, but also gradually leads to rejection of self".

Teacher's self-acceptance leads to positive acceptance of schoolchildren. Teachers, who accept their self, have an understanding attitude toward the schoolchildren and strive to create an atmosphere of security, trust and care that contributes to children's desire to be whom they are. 
The other important component of class teachers' psychological culture is their emotional culture. It is necessary for every teacher and its development begins with attempts to analyze one's emotional experience, to listen oneself carefully, separating true unconditional emotions from destructive judgments.

Successful implementation of this behavior is largely dependent on the quality of one's emotional life. There are certain forms of emotional behavior in the general culture that facilitate effective interpersonal communication and underlie people's social competence. These forms and individual experience are interconnected within personality and constitute one of its complex aspects which manifest itself in compassion, empathy and emotional self-regulation, and can be described as emotional culture. Emotional culture is a part of general culture, and is an integral part of personality, which characterizes one's attitude towards creative activity and allows one to perceive, express, understand and regulate emotions.

The emotional culture of a class teacher is an indicator of his or her general psychological culture. Education has high expectations for emotional sphere of teachers. The most prominent signs of teacher's emotional culture are high level of emotional resilience, empathy and emotional flexibility. Emotional culture reflects the level of professionalism, emotional maturity and influences reputation of a teacher.

Therefore, the emotional culture of a class teacher is:

- an ability to understand and know oneself (strengths and weaknesses, feelings and behaviors);

- an ability to regulate oneself (attitudes, behavior, decision-making, persistence, flexibility, coping with stress and resolution of conflicts, control over emotions);

- an ability to motivate oneself (set goals and plan actions, achieving goals, positive attitude, joy of life and satisfaction from work);

- an ability to understand others, their emotions, feelings, reasons, behavior, be patient;

- an ability to build relationships with the others (trust, respect, flexibility, teamwork).

Psychological culture of class teacher includes one more important component - the culture of teacher's influence (Orlov, 2002). Culture of pedagogical influence implies replacing authoritarian direct influence on children with the developmental one. In this case the main and 
primary concern of a class teacher is creating positive environment for unhindered intellectual, moral, aesthetic, and any other development of schoolchildren, i.e., the development in accordance with children's own goals, intentions and aspirations.

Successful work of a class teacher brings class together, preparing schoolchildren for the adult life. A teacher must continually improve the teaching methods, keeping in mind the importance of his or her influence on the future of schoolchildren.

In psychology, there is discernment between directed and undirected influence. The first employs persuasion and suggestion. Here a class teacher seeks to achieve a certain result of the pupils. In contrast, the undirected influence has no any special task, and the educational effect is produced by imitating the behavior of a role-model. The non-verbal means of influence are also of certain importance, because with their help it is easy to express the attitude towards a schoolchild, weaken his or her psychological defense and invade the world of the child's senses. Among these are certain facial expressions, gestures, and expressive means of voice (pitch, rhythm of speech, pauses, laughter, and other), eye contact, and tactile contact.

The choice of an educational strategy or of kind of influence is always left to a teacher. Teachers simply need to remember that "it takes a personality to form a personality, and it takes character to form character". A teacher must be a Person, as it is his of her professional characteristics. Therefore, the development of future teachers' psychological culture that would serve as a mechanism for effective communication, understanding, and communication between people of different nationalities, age, gender, occupation and other characteristics, is the basis of the psychological safety of both modern schoolchildren and the educational environment in general.

\section{References}

Allakhverdov, V.M., Beljak, N.V., \& Ivanov, M.V. (1985). O formirovanii psihologicheskoj kul'tury u studentov tehnicheskogo vuza [On the formation of psychological culture of students of technical high school]. Psihologicheskoe obespechenie uchebnovospitatel'nogo processa $v$ vuze [Psychological support of the educational process in college]. Leningrad: LGU. 
Ananiev, B.G. (2001). Chelovek kak predmet poznanija [Human as an object of knowledge]. St. Petersburg: Piter.

Basov, M.Ya. (1975). Izbrannye psihologicheskie proizvedenija [Selected psychological works]. Moscow: Pedagogika.

Bodalev, A.A. (2002). Psihologija obshchenija: Izbrannye psihologicheskie trudy [Psychology of communication: Selected psychological works], 2nd ed. Moscow: Moskovskij psihologo-social'nyj institut; Voronezh: NPO «MODJeK».

Dubrovina, I.V. (Ed.). (2000). Psihicheskoe zdorov'e detej i podrostkov $v$ kontekste psihologicheskoj sluzhby [Mental health of children and adolescents in the context of psychological services]. Ekaterinburg: Delovaja kniga.

Zimnyaya, I.A. (2005). Obshchaja kul'tura i social'no-professional'naja kompetentnost' cheloveka [General culture and social and professional competence of the person]. Vysshee obrazovanie segodnja [The higher education today], 11, 14-20.

Zinchenko, V.P., \& Morgunov, E.G. (1994). Chelovek razvivajushchijsja: Ocherki rossijskoj psihologii [Developing person: Essays on Russian psychology]. 2nd ed. Moscow: Trivola.

Klimov, E.A. (2004). Vvedenie v psihologiju truda [Introduction to labour psychology]. Moscow: Moscow State University.

Kolmogorova, L.S., \& Holodkova, O.G. (2001). Osobennosti stanovlenija psihologicheskoj kul'tury mladshih shkol'nikov [Features of the formation of psychological culture of junior school children]. Voprosy Psychologii [Psychology Issues], 1, 47-56.

Kulikov, L.B. (1995). Psihologicheskaja kul'tura jetnosa [Psychological culture of ethnos]. In Yu. Platonov (Ed.), Vvedenie v jetnicheskuju psihologiju: Ucheb. posobie [Introduction to Ethnic Psychology: Handbook] (pp. 158-169). St. Petersburg: SPbGU.

Kulikova, T.I. (2008). Klassnyj rukovoditel': professional'naja kompetentnost' i psihologicheskaja kul'tura [Class teacher: professional competence and psychological culture]. Tula: Levsha.

Motkov, O.I. (1999). Psihologicheskaja kul'tura lichnosti [Psychological culture of personality]. Shkol'nyj psiholog [School psychologist], 8 .

Obozov, N.N. (1986). Psihologicheskaja kul'tura vzaimnyh otnoshenij [Psychological culture of mutual relations]. Moscow: Znanie.

Orlov, A.B. (2002). Psihologija lichnosti i sushchnosti cheloveka: Paradigmy, proektsii, praktiki: Ucheb. posobie [Personality psychology and human nature: Paradigms, projections, practice: Handbook]. Moscow: Akademija. 